\title{
The Preparation of Apurinic Acids and A New Method for the Quantitative Determination of the Purine Contents of Deoxyribonucleic Acids
}

\author{
S. G. L A L A N D \\ Institutt for Erneringsforskning, Universitet, Oslo, Norway
}

\begin{abstract}
Tt has been demonstrated ${ }^{1,2}$ that the purine deoxyribonucleosides on treat1 ment with an acidic type of resin, such as Amberlite IR-120 (H) in the hydrogen form, are hydrolysed to the purines and the free sugars. This finding suggested that the contact of an aqueous solution of deoxyribonucleic acid (DNA) with such a resin would result in the liberation of the purines with the simultaneous formation of the so called apurinic acid ${ }^{3}$. When liberated, the purines would be retained by the acidic resin and the aqueous solution should contain only apurinic acid.

The present paper describes the preparation of the apurinic acids from the DNA's isolated from the following sources: calf thymus gland, soft herring and cod roe, wheat germ and Mycobacterium phlei by a method which involves treatment of their aqueous solutions with Amberlite IR-120 (H). In addition a quantitative micro-method for the determination of the purines of DNA based on the removal of purines by the resin is described, and applied to the above mentioned DNA's.
\end{abstract}

\section{EXPERIMENTAL}

Preparation of resin. Amberlite IR-120 (H) (50 g, 40-60 mesh) was treated with hydrochloric acid $(11,4 \mathrm{~N})$ in a column, washed free of acid with water, washed with alcohol $(200 \mathrm{ml})$, ether $(200 \mathrm{ml})$ and finally dried at $60^{\circ} \mathrm{C}$ until free from ether. This product was used in all the subsequent experiments.

Deoxyribonucleic acids. The DNA's from calf thymus gland, soft herring roe, wheat germ and $M$. phlei employed in the present investigations were those described in a previous publication * (DNA from calf thymus gland preparation $T_{1}$, and DNA from hering roe was $H_{1}$ ). The DNA used from soft cod roe has been described in a recent paper ${ }^{1}$.

Nitrogen and phosphorus analyses. The methods described in a following paper were used 2 .

Standard purines. Adenine (supplied by B.D.H, Ltd.) was purified by recrystallisation once from hot water. Guanine (supplied by B.D.H, Ltd.) was recrystallised according to the procedure of Horbaczewski ${ }^{5}$. The recrystallised products were dried over

Acta Chem. Scand. 8 (1954) No. 3 
phosphorus pentoxide in vacuum $(20 \mathrm{~mm} \mathrm{Hg})$ at $110^{\circ} \mathrm{C}$. The molecular extinction coefficients in hydrochloric acid $(4 N)$ of the standard adenine and guanine' were determined in the Beckmann spectrophotometer at four wavelengths. These were:

$\begin{array}{lcccc} & 270 \mathrm{~m} \mu & 260 \mathrm{~m} \mu & 250 \mathrm{~m} \mu & 245 \mathrm{~m} \mu \\ \text { Adenine } & 9700 & 11150 & 9350 & 7600 \\ \text { Guanine } & 5450 & 8300 & 10200 & 10200\end{array}$

$$
\text { Preparation of apurinic acid from calf thymus }
$$

An aqueous solution (40 ml) of DNA from calf thymus gland $(1 \mathrm{mg} / \mathrm{ml}$ approx., freeze-dried material) and Amberlite IR-120 (H) (5.7 g) were mixed in a flask fitted with a quick fit stopper and shaken gently at room temperature. The initial ultra violet absorption of the DNA solution was determined by diluting an aliquot $(0.3 \mathrm{ml})$ with phosphate buffer (to $5 \mathrm{ml}$ with $0.1 M$ buffer, $\mathrm{pH} \mathrm{7.0)}$ and examining the solution at $260 \mathrm{m \mu}$ in the Beckmann spectrophotometer. At intervals (i.e. every day) the ultra violet absorption of the solution being treated with the resin was determined in the same way. After fourteen days the resin was filtered off, washed with water $(10 \mathrm{ml})$, the solution neutralised with dilute alkali to $\mathrm{pH} 7.0$ and evaporated to dryness in the frozen state. $25 \mathrm{mg}$ of a white product was obtained. It was analysed for nitrogen and phosphorus and the atomic $\mathbf{N} / \mathbf{P}$ ratio calculated.

\section{General method for the determination of the purines of D N A}

DNA (approx. $7 \mathrm{mg}$, freeze-dried material) was dissolved in water $(7 \mathrm{ml}$ ) and part of the solution (5 ml) was transferred to a small flask (volume $10 \mathrm{ml}$ ) containing Amberlite IR-120 (H) (0.72 g). The flask was closed with a slightly greased quick fit stopper. It was then shaken gently at room temperature for twelve days. The total phosphorus content of the solution $(5 \mathrm{ml})$ was calculated by determining the content of an aliquot $(0.4 \mathrm{ml})$ of the remaining of the original DNA solution. In addition the ultra-violet absorption spectrum was determined by diluting an aliquot $(0.3 \mathrm{ml}$ ) with buffer (to $5 \mathrm{ml}$ with $0.1 M$ phosphate buffer, $\mathrm{pH}$ 7.0) and examining the diluted solution in the Beckmann spectrophotometer in the range $230-290 \mathrm{~m} \mu$. When twelve days had elapsed the solution was filtered from the resin using a small glass column (diameter $1.3 \mathrm{~cm}$, length 9.5 em) fitted with a glass disc which served as a filter. The column was connected with a filtering tube and the water pump. The filtrate containing the apurinic acid was analysed for phosphorus by withdrawing aliquots $(0.4 \mathrm{ml})$ and the ultra-violet absorption spectrum determined as above (this latter spectrum and that of the original DNA are not required for the determination of the purines). The remaining of the filtrate was neutralized with sodium hydroxide and the apurinic acid isolated after evaporation in the frozen state in vacuum.

The resin was transferred quantitatively from the flask to the column with some water $(20 \mathrm{ml}$ ) and washed (with $20 \mathrm{ml}$ of water). To remove the purines, the resin was eluted with hydrochloric acid $(4 \mathrm{~N}, 100 \mathrm{ml})$ at a rate of approximate $1 \mathrm{ml} / \mathrm{min}$. The eluate was collected in a volumetric flask $(100 \mathrm{ml})$. Examination of subsequent eluate at 260 $\mathrm{m} \mu$ indicated that the volume used for elution was sufficient to remove the purines quantitatively. The ultra-violet absorption of the eluate was determined in $1 \mathrm{~cm}$ cells at several wavelengths using $4 N \mathrm{HCl}$ as a blank. The amounts of adenine and guanine present in the eluate could be calculated by using the following formulae:

$$
\begin{gathered}
\text { Adenine (in } \mu \mathrm{g} \text { ) }=\frac{E \lambda_{1} \cdot G \lambda_{2}-E \lambda_{2} \cdot G \lambda_{1}}{A \lambda_{1} \cdot G \lambda_{2}-A \lambda_{2} \cdot G \lambda_{1}} \cdot A \cdot 100 \\
\text { Guanine (in } \mu \mathrm{g} \text { ) }=\frac{E \lambda_{1}-\frac{\text { Adenine } \cdot A \lambda_{1}}{100 \cdot A}}{G \lambda_{1}}
\end{gathered}
$$


Formulae (a) and (b) were obtained by solution of the following two equations:

$$
\begin{aligned}
& \text { Adenine } \cdot \frac{A \lambda_{1}}{A}+\text { Guanine } \cdot \frac{G \lambda_{1}}{G}=E \lambda_{1} \cdot 100 \\
& \text { Adenine } \cdot \frac{A \lambda_{2}}{A}+\text { Guanine } \cdot \frac{G \lambda_{2}}{G}=E \lambda_{2} \cdot 100
\end{aligned}
$$

In the two formulae, $E \lambda_{1}$ and $E \lambda_{2}$ designate the optical densities at the two wavelengths $\lambda_{1}$ and $\lambda_{2}\left(\lambda_{1}>\lambda_{2}\right)$. Two sets of wavelengths were used for the calculations: 270 and 250 $\mathrm{m} \mu$, as well as 260 and $245 \mathrm{~m} \mu \cdot G \lambda_{1}, G \lambda_{2}, A \lambda_{1}$ and $A \lambda_{2}$ are the optical densities of the standard adenine and guanine solutions (in $4 N \mathrm{HCl}$ ) in $1 \mathrm{~cm}$ cells at the two wavelengths, and $A$ and $G$ the concentrations (in $\mu \mathrm{g} / \mathrm{ml}$ ) of the standard solutions. All concentrations of purines determined in this investigation are the mean values of the figures obtained by calculations at the two sets of wavelengths mentioned above. The formulae (a) and (b) are similar to those used by Laland et al..$^{4}$ for the determination of amounts of adenine and cytosine in a mixture, and to those described by Chargaff et al..$^{6}$ for the determination of mixture of uridylic acid and cytidylic acid and now recently for adenine and guanine ${ }^{8}$.

\section{Chromatographic analyses of the apurinic acids}

The apurinic acid $(2 \mathrm{mg})$ was heated with perchloric acid $7(0.4 \mathrm{ml}, 35 \%)$ on a boiling water bath for 90 minutes. An aliquot of the hydrolysate $(0.05 \mathrm{ml}$, containing approx. $0.035 \mathrm{mg}$ of phosphorus) was put on a paper chromatogram, developed with the isopropanol-hydrochloric acid mixture $(65 \%$ aqueous isopropanol $(\mathrm{v} / \mathrm{v}), 2 \mathrm{~N}$ with respect to hydrochloric acid) of Smith and Wyatt ${ }^{8}$ and the chromatogram photographed according to the technique of Markham and Smith ". In all the apurinic acids examined, the chromatograms revealed the presence of the pyrimidines but only traces of the purines were detectable.

\section{CONTROL EXPERIMENTS}

Estimations of prepared mixtures of adenine and g u a n in e

Guanine $(454 \mu \mathrm{g})$ in dilute hydrochloric acid solution $(0.1 \mathrm{~N}, 0.5 \mathrm{ml})$ and adenine $(440 \mu \mathrm{g})$ also in hydrochloric acid solution $(0.1 \mathrm{~N}, 0.25 \mathrm{ml})$ were mixed with water $(5 \mathrm{ml})$ and Amberlite IR-120 (H) (0.72 g) in a small flask. The flask was kept at room temperature for two hours with occasional shaking. The resin was filtered off quantitatively in the manner described in the section of the purine determination of the DNA's. Examination of the filtrate in the spectrophotometer at $260 \mathrm{~m} \mu$ indicated that negligible amounts of purines were left in the filtrate. The purines absorbed by the resin were eluted with hydrochloric acid $(100 \mathrm{ml}, 4 \mathrm{~N})$. The ultra-violet absorptions of the eluate at 270 and 250 $\mathrm{m} \mu$, as well as that at 260 and $245 \mathrm{~m} \mu$ were used to calculate the amounts of adenine and guanine by application of the formulae previously given in this paper.

\section{Resin blank}

To determine the ultra-violet absorption of the eluate of the resin used in the determination of the purines, the following experiment was carried out. Amberlite IR-120(H) $(0.72 \mathrm{~g})$ was shaken in the usual manner with water $(5 \mathrm{ml})$ for twelve days at room temperature. The resin was then filtered off and eluted as described previously. The eluate was examined against hydrochloric acid $(4 N)$ at $270,260,250$ and $245 \mathrm{~m} \mu$ and exhibited negligible absorption (approx. 0.01 in optical density). 


\section{Liberation of purines duetothe acidity of a D A solution when mixed with IR-120 (H)}

DNA solution (5 ml, approx. $1 \mathrm{mg} / \mathrm{ml}$ ) was mixed with Amberlite IR-120(H) (0.72 g) and left at room temperature with occasional shaking, and the resin filtered off after one hour. A few drops of chloroform were added to the filtrate to prevent growth. The solution was kept in a stoppered flask at room temperature for fourteen days, and then neutralized with dilute alkali. Phosphorus analysis were carried out on aliquots $(0.5 \mathrm{ml})$. The presence of any free purines in the solution was determined by quantitative paper chromatography $(0.25 \mathrm{ml}$ of the solution was put on the chromatogram). Three determinations were carried out. The chromatograms were developed with a mixture of $n$ butanol and aqueous ammonia $(0.6 \mathrm{~N})(6: 1, \mathrm{v} / \mathrm{v})^{10}$. The ultra violet prints of the chromatograms indicated the presence of two minor spots having $R_{F}$ values identical with that of adenine and guanine, respectively. The spots were cut out and eluted with hydrochloric acid $(3 \mathrm{ml}, 0.1 \mathrm{~N})$ and the amounts of purines determined quantitatively by ultra-violet spectroscopy.

\section{Examination of the eluate of the resin containing the purines}

Part of the hydrochloric acid eluate $(40 \mathrm{ml})$ of the resin containing the purines from calf thymus DNA (approx. $5 \mathrm{mg}$ ) (see the section for the determination of the purines), was added ethanol $(200 \mathrm{ml})$ and concentrated in vacuum. When concentrated to a small volume (approx. $10 \mathrm{ml}$ ) further addition of ethanol was made and concentration again carried out. This was repeated three times after which time the hydrochloric acid was practically removed. The final volume was $1 \mathrm{ml}$ and aliquots were examined by paper chromatography using the isopropanol-hydrochloric acid mixture ${ }^{8}$. The ultra-violet print of the chromatograms demonstrated the presence of only adenine and guanine. Analysis of the concentrate $(0.5 \mathrm{ml})$ revealed the absence of phosphorus.

\section{RESULTS AND DISCUSSION}

Apurinic acids. On treatment of an aqueous solution of the sodium salt of DNA from calf thymus with Amberlite IR-120 (H) in the hydrogen form at room temperature, a rapid increase in the ultra violet absorption at $260 \mathrm{~m} \mu$ takes place: Fig. 1. This can be explained in the following way. When treating the DNA solution with the resin, a partly exchange of the sodium ions and the hydrogen ions of the resin occurs which results in a fall in $\mathrm{pH}$ to $2.7-$ 2.9. It is well known fact that such a change in the pH of a native DNA solution is followed by an increase in the ultra-violet absorption ${ }^{11}$.

It appears from Fig. 1 that on continued treament of the DNA solution with the resin, a slow decrease in the ultra-violet absorption takes place, reaching a steady state after twelve days. The decreased ultra-violet absorption has been shown to be due to the complete liberation of the purines with the subsequent absorption of the latter by the resin. This was demonstrated by paper chromatography of the hydrolysate of the material remaining in the solution, and of the hydrochloric acid eluate of the resin. It is reasonable to assume that before any molecule is hydrolysed by a resin, it must at least be located on its surface. The macromolecules of DNA will be attracted to the sulphonic acid groups of the resin because of the amino groups of the former. The DNA molecules are far too large to enter the small pores of the resin and therefore only the surface can accommodate the molecules to be hydrolysed. 
Fig. 1. Changes in optical density at $260 \mathrm{m \mu}$ of a solution of calf thymus DNA on treatment with Amberlite IR-120(H).

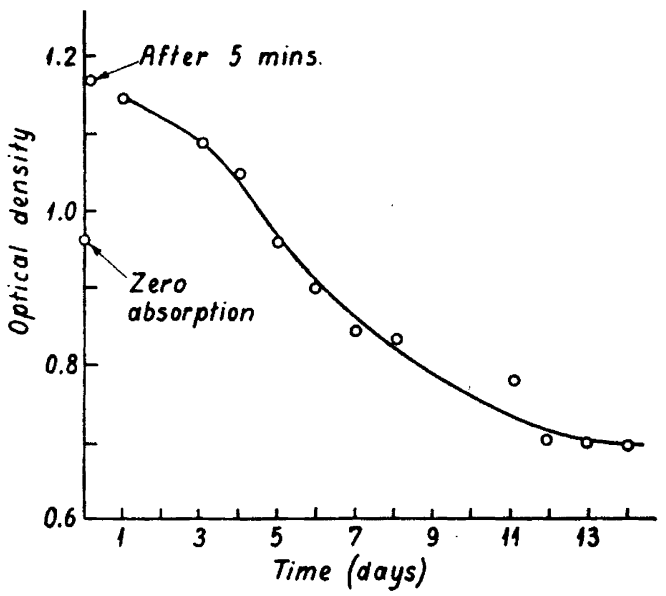

On the other hand, smaller molecules such as the deoxyribonucleosides which have been shown to be hydrolysed very rapidly by the resin are accommodated by the whole resin particle. Thus the rate of liberation of the purines from DNA would be expected to be very much slower than for instance in the case of the purine nucleosides. This is borne out by the time (12 days) required for the complete removal of the purines in the DNA, compared with the almost instantaneous hydrolysis of the purine deoxyribosides 1,2 .

The acid $\mathrm{pH}(2.7-2.9)$ of the solution of DNA being treated with the acidic resin could, in part, be responsible for the liberation of the purines. Experiments demonstrated that in the case of DNA from calf thymus, 13.4 and $17.9 \%$ of the total adenine and guanine respectively were liberated because of the acidity of the solution. Thus under the present experimental conditions the resin was responsible for the liberation of more than $80 \%$ of the purines.

In the method of Chargaff et $a l .^{3}$ for the preparation of apurinic acid, a solution of DNA with $\mathrm{pH} 1.6$ at $37^{\circ} \mathrm{C}$ is dialysed in a cellophane bag against a buffered solution of the same $\mathrm{pH}$. The method presented in this paper would seem to have some advantages over Chargaff's method. The reaction proceeds at a higher $\mathrm{pH}$ and at a lower temperature than that used by Chargaff et al..$^{3}$, and consequently less degradation is likely to occur. When isolating the apurinic acid it is only necessary to filter off the resin from the solution, and the product can be obtained in pure state upon lyophilization of the filtrate. Paper chromatography and phosphorus analyses of the eluate of the resin demonstrated that the former removed purines only from the DNA solution. The phosphorus concentration of the DNA solution had increased slightly $(2 \%)$ after the treatment with the resin, because of the absorption of some water by the anhydrous resin. The yield of apurinic acid by the present method is necessarily $100 \%$. The apurinic acid from DNA from calf thymus had an atomic nitrogen over phosphorus ratio of 1.39 , which

Acta Chem. Scand. 8 (1954) No. 3 


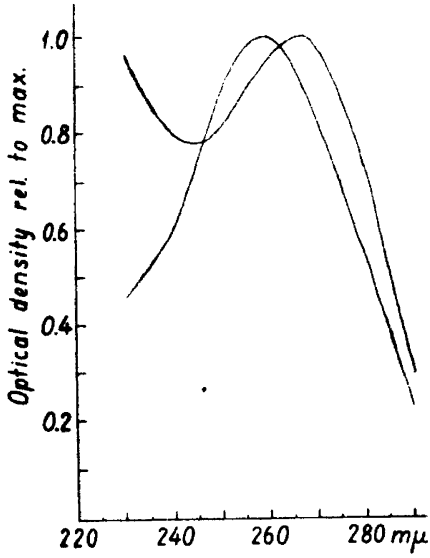

Fig. 2.

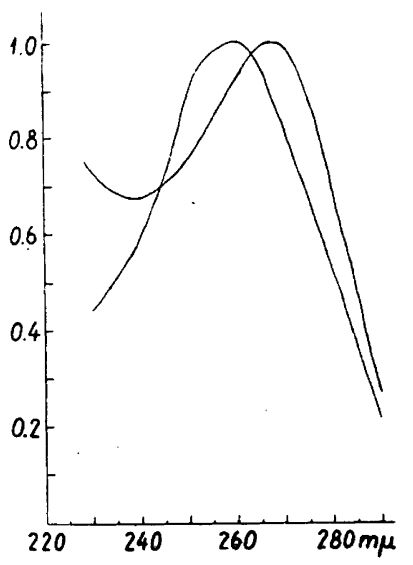

Fig. 5.

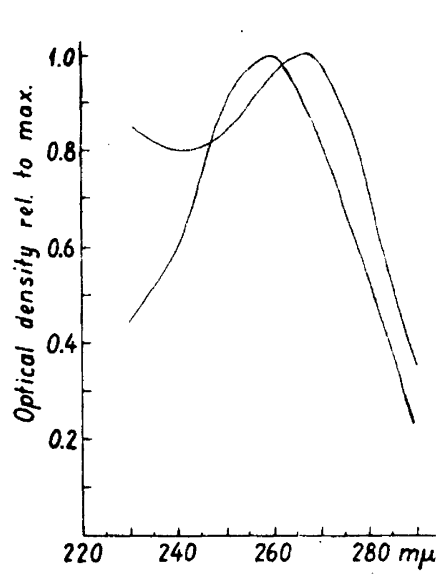

Fig. 3.

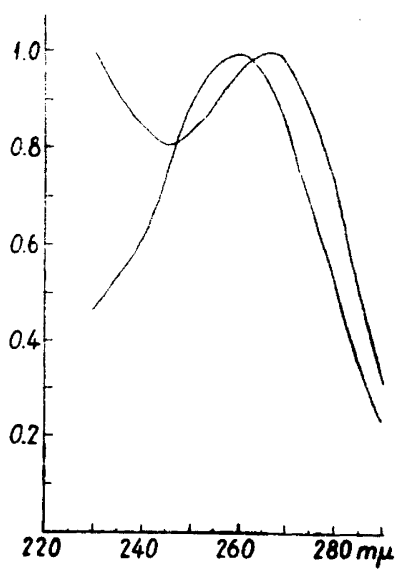

Fig. 4.

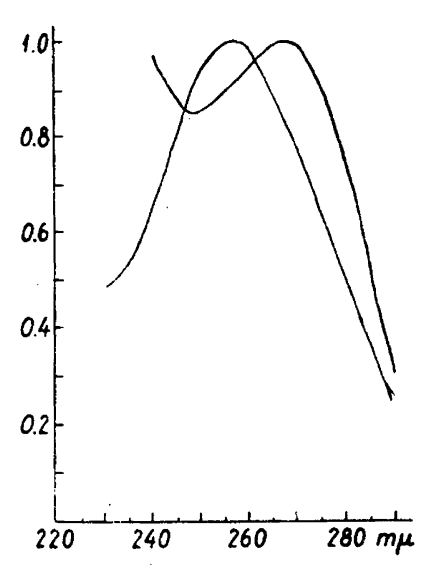

Fig. 6.

Figs. 2, 3, 4, 5 and 6 represent the ultra-violet absorption spectra at pH 7.0 in phosphate buffer of apurinic acids and the parent DNA's isolated respectively from the following sources: calf thymus, herring roe, cod roe, wheat germ and $M . p h l e i$. In every figure the ultra-violet absorption spectrum with the maximum of absorption at the lowest wavelength is that of the DNA and the other spectrum is that of the corresponding apurinic acid.

is close to that reported by Chargaff et al. ${ }^{3}$ (1.40 and in some cases 1.20.) It reduced Fehling solution upon heating and reacted on a piece of filter paper when heated with aniline hydrogen phthalate.

Apurinic acids prepared by the resin method from the other DNA's examined in this investigation, were shown to be devoid of purines. The ultra violet absorption of all the apurinic acids and their corresponding DNA's are shown in the Figs. 2, 3, 4, 5 and 6. It is seen from these Figs. that in all the apurinic acids the ultra-violet absorption maximum is shifted towards

Acta Chem. Scand. 8 (1954) No. 3 
higher wavelength i.e. 268 and $269 \mathrm{~m} \mu$, when compared with parent DNA. Chargaff et al. ${ }^{3}$ report similar result in the case of apurinic acid from calf thymus DNA.

Table 1 demonstrates that the decrease in the value of $\varepsilon(\mathrm{P})_{260}$ (atomic extinction coefficient with regard to phosphorus ${ }^{12}$ ) when a DNA is converted to the corresponding apurinic acid is in the range of $1800-2200$ in the six cases examined, and consequently does not differ a great deal in DNA's from such different sources as $e . g$. calf thymus and M.phlei.

Table 1. Molecular extinction coefficients with regard to phosphorus at $\mathrm{pH} 7.0$ for DNA's and the corresponding apurinic acids.

\begin{tabular}{|l|c|c|}
\hline Source of DNA & $\begin{array}{c}\varepsilon(\mathbf{P})_{280} \\
\text { for DNA }\end{array}$ & $\begin{array}{c}\varepsilon(\mathbf{P})_{280} \\
\text { for apurinic acid }\end{array}$ \\
\hline Calf thymus & 6300 & 4350 \\
Herring roe & 6500 & 4300 \\
Cod roe & 6900 & 4700 \\
Wheat germ & 6600 & 4750 \\
$M$. phlei & 6250 & 4450 \\
\hline
\end{tabular}

The freeze-dried apurinic acids from calf thymus DNA darkens on storage in a dark bottle; this has also been noticed for the apurinic acids prepared from herring roe, cod roe, wheat germ and M.phlei DNA's. Whether this is due to a reaction of the free aldehyde groups of the apurinic acid with traces of proteins present in the original DNA or to intermolecular reactions in the apurinic acid, can not be decided upon at the moment.

Determination of purines. The complete removal of the purines from a DNA by Amberlite IR-120(H) led to the development of a micro-method for the determination of the former. In order to check the method, known amounts of adenine and guanine were determined under experimental conditions similar to those used in the determination of the purines of a DNA. The results are presented in Table 2.

Table 2. Determination of known amounts of a mixture of adenine and guanine.

\begin{tabular}{|l|c|c|}
\hline \multirow{2}{*}{ Theory } & Adenine $(\mu \mathrm{g})$ & Guanine $(\mu \mathrm{g})$ \\
\cline { 2 - 3 } & 440 & 454 \\
Found when calc. & 440 & 453 \\
at 270 and 250 $\mathrm{m} \mu$ & & \\
$\begin{array}{l}\text { Found when calc. } \\
\text { at 260 and 250 } \mathrm{m} \mu\end{array}$ & 440 & 450 \\
\hline
\end{tabular}

The determination of the purines of a DNA as carried out in this investigation requires only $6-7 \mathrm{mg}$ of material. However, if necessary, $3-3.5 \mathrm{mg}$ of DNA can be used by reducing the amount of resin and the volume of the eluate to the half.

Acta Chem. Scand. 8 (1954) No. 3 


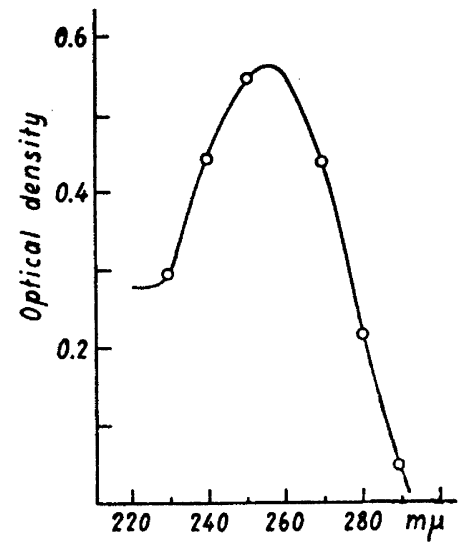

Fig. 7. The drawn curve is the ultra-violet absorption spectrum of the resin eluate containing the purines from calf thymus $D N A$. The open circles are the theoretical values for the ultra violet absorption.

The deviation in separate analyses of the determination of the purines in DNA is demonstrated in Table 3. Each set of figures are the mean values of the figures obtained by calculation at the two sets of wavelengths mentioned. in the experimental section.

Table 3. Separate analyses of the purine content of the DNA's from calf thymus and wheat germ.

\begin{tabular}{|c|c|c|c|}
\hline \multirow[t]{2}{*}{$\begin{array}{c}\text { Analysis } \\
\text { No. }\end{array}$} & \multirow[t]{2}{*}{$\begin{array}{l}\text { Source of } \\
\text { of DNA }\end{array}$} & \multicolumn{2}{|c|}{$\begin{array}{c}\text { Moles of purines per } 4 \text { atoms } \\
\text { of phosphorus }\end{array}$} \\
\hline & & Adenine & Guanine \\
\hline $\begin{array}{l}1 \\
2 \\
1 \\
2 \\
\end{array}$ & $\begin{array}{l}\text { Calf thymus } \\
\text { Calf thymus } \\
\text { Wheat germ } \\
\text { Wheat germ }\end{array}$ & $\begin{array}{l}0.97 \\
1.05 \\
0.98 \\
0.975 \\
\end{array}$ & $\begin{array}{l}0.73 \\
0.795 \\
0.78 \\
0.795 \\
\end{array}$ \\
\hline
\end{tabular}

The figures for the two wheat.germ analyses agree well, but the agreement is not quite so good in the case of calf thymus DNA. However, the ratio adenine/ guanine is very nearly the same in the two analyses (the ratio is 1.33 and $\mathbf{1 . 3 2}$ respectively). Variations in separate analyses as here presented are largely due to variations in the phosphorus determination and less to the determinations of the purines.

The ultra-violet absorption spectrum of a resin eluate agrees with the theoretical values. In Fig. 7 the drawn curve shows the ultra-violet absorption spectrum of the resin eluate containing the purines from calf thymus DNA. The open circles represent the theoretical values for the ultra-violet absorption at several wavelengths. These values have been calculated from the ultra violet absorption of the standard purine solutions, and from the results of calculations of the amounts of adenine and guanine in the eluate. These were calculated by means of the ultra-violet absorption of the eluate at 260 and $245 \mathrm{~m} \mu$. 
Table 4 summarises the results of the purine analyses of a number of DNA's by the method described in this paper. In brackets are quoted the figures reported in an earlier paper ${ }^{7}$, and obtained by quantitative paper chromatography of hydrolysates of the same specimens. (No figures reported for cod roe DNA.)

Table 4. The purine contents of DNA's.

\begin{tabular}{|c|c|c|c|}
\hline Source of DNA & \multicolumn{3}{|c|}{ Moles of purines per 4 atoms of phosphorus } \\
\hline \multirow[b]{2}{*}{ Calf thymus } & Adenine & \multicolumn{2}{|c|}{ Guanine } \\
\hline & $1.01 \quad(0.99)$ & 0.76 & $(0.77)$ \\
\hline Herring roe & $0.95 \quad(1.0)$ & 0.73 & $(0.71)$ \\
\hline $\begin{array}{l}\text { Cod roe } \\
\text { Wheat germ }\end{array}$ & $\begin{array}{ll}0.94 \\
0.98 & (0.90)\end{array}$ & $\begin{array}{l}0.79 \\
0.79\end{array}$ & $(0.67)$ \\
\hline M.phlei ${ }^{\circ}$ & $\begin{array}{ll}0.50 & (0.57)\end{array}$ & 1.14 & (1.0) \\
\hline
\end{tabular}

'The figures reported for the DNA's from wheat germ and calf thymus are the mean of the figures given in Table 3.

The determination of purines in a DNA by paper chromatography usually involves the use of acid hydrolysis (formic acid or perchloric acid) at high temperature, prior to the chromatographic separation of the purines and pyrimidines. This rather drastic treatment is likely to destroy some of the purines. In this respect the present method is probably preferable since the purine determination is carried out at room temperature, and consequently less destruction of the purines should occur. Admittedly the total time required for the purine analysis according to the present method is long, but it should be borne in mind that the actual time required is not more than that of quantitative paper chromatography. By raising the temperature at which the present purine analysis is carried out to e.g. $37^{\circ} \mathrm{C}$ a reduction in the total time could be achieved. No attempt, however, has yet been made to carry out the analysis at this temperature.

Finally it is natural to consider the possible extension of the methods discussed in this paper to ribosenucleic acids (RNA). Undoubtedly, the lability of the purines in RNA suggests that these methods could be applied to this group of nucleic acids.

\section{SUMMARY}

1. A new method for the preparation of apurinic acid from DNA is described and applied to number of different DNA's. The method involves the use of a sulphonic acid type of resin.

2. A micro-method for the determination of the purines in DNA requiring $6-7 \mathrm{mg}$ material is reported and applied to several DNA's. The results are compared with those obtained by quantitative paper chromatography.

The author wishes to thank Norges Almenvitenskapelige Forskningsråd for financial support.

Acta Chem. Scand. 8 (1954) No. 3 


\section{REFERENCES}

1. Laland, S. G. and Overend, W. G. Acta Chem. Scand. 8 (1954) 192.

2. Jones, A. S. and Laland, S. G. Acta Chem. Scand. 8 (1954) In press.

3. Tamm, C., Hodes, M. E. and Chargaff, E. J. Biol. Chem. 195 (1952) 49.

4. Laland, S. G., Overend, W. G. and Webb, M. J. Chem. Soc. 19512450.

5. Horbaczewski, J. Hoppe-Seylers Z. physiol. Chem. 23 (1897) 229.

6. Magasanik, B., Vischer, E., Doniger, R., Elson, D. and Chargaff, E. J. Biol. Chem. 186 (1950) 37.

7. Marshak, A. and Vogel, H. J. J. Biol. Chem. 189 (1951) 599.

8. Smith, J. D. and Wyatt, S. R. Biochem. J. (London) 49 (1951) 144.

9. Markham, R. and Smith, J. D. Biochem. J. (London) 45 (1949) 294.

10. Chargaff, E., Lipshitz, R., Green, C. and Hodes, M. E. J. Biol. Chem. 192 (1951) 223.

11. Shack, J., Jenkins, R. J. and Thompsett, J. J. Biol. Chem. 203 (1953) 373.

12. Zamenhof, S. and Chargaff, E. J. Biol. Chem. 173 (1948) 327.

Received November 18, 1953. 